УДК 577.359

\title{
DO CARBON NANOTUBES INHIBIT OR PROMOTE AMYLOID FIBRILS FORMATION?
}

\author{
M.V. Olenchuk ${ }^{1}$, O.P. Gnatyuk ${ }^{1}$, G.I. Dovbeshko ${ }^{1}$, I.O. Polovyi ${ }^{1}$, S.O. Karakhim ${ }^{2}$ \\ ${ }^{I}$ Institute of Physics of NASU, Nauky Avenue, 46, Kyiv, 03028, Ukraine \\ ${ }^{2}$ Palladin Institute of Biochemistry of NASU, Leontovycha St. 9, Kyiv, 01601, Ukraine \\ e-mail:ipoliovy@gmail.com \\ Submitted October 5, 2018 \\ Accepted February 5, 2019
}

Background: Carbon nanotubes, due to their unique physical properties, have been widely used in materials science and electronics; however, numerous attempts to create systems for delivering drugs or complexes of therapeutic drugs with nanotubes for improving their effectiveness and specificity have not succeeded. It is primarily due to the high cytotoxicity of nanotubes for living cells as well as the lack of mechanisms for their biodegradation. On the other hand, carbon nanotubes can form stable compounds with such biologically important molecules as DNA, phospholipids, proteins. In this paper, the possibility of the formation of amyloid fibril structures in lysozyme due to the interaction with carbon nanotubes is shown. The obtained results have both a fundamental and an applied value, since this may be a method for obtaining model amyloid fibrils for further study.

Objectives: The purpose of the work was to study the effect of carbon nanotubes on the formation of fibril structures in lysozyme at room temperature under different $\mathrm{pH}$ values.

Materials and methods: For the preparation of the samples, hen egg-white lysozyme protein (HEWL, Fluka), as well as single-walled (SWCNT, Sigma-Aldrich) and multi-walled (MWCNT, OOO TM "Spetsmash", Kyiv, Ukraine) carbon nanotubes were used. Used techniques: IR-Fourier Absorption Spectroscopy; confocal microscopy.

Results: In this paper, the study of molecular mechanisms of interaction of lysozyme with carbon nanotubes by vibrational spectroscopy was carried out and a conformational analysis of the formed complexes was performed. It is shown that carbon nanotubes can affect the structure of lysozyme even at room temperature and normal $\mathrm{pH}$ values, as evidenced by conformational changes in lysozyme due to interaction with carbon nanotubes. Complexes which are formed as a result of such interaction, have characteristic features of amyloid fibrillar structures. It reveals one of possible mechanisms of carbon nanotubes cytotoxicity. On the other hand, such a technique can be introduced to obtain model amyloid fibrils for further study.

Conclusion: The method of vibtarional spectroscopy has shown that carbon nanotubes can influence the structure of lysozyme, as it is shown by the conformational analysis of the absorption band Amide I. After the interaction of lysozyme with CNT, an increase in the contribution of antiparallel $\beta$-conformation in the structure of lysozyme is observed, and the contribution of the $\alpha$-helix conformation is reduced, which are characteristic features in the formation of fibrillar structures. The possibility of amyloid fibril formation without the use of high temperatures at different $\mathrm{pH}$ values with the interaction of lysozyme and carbon nanotubes, which can be applied as a method for obtaining the model amyloid fibrils, is shown.

KEY WORDS: amyloid fibril; lysozyme; carbon nanotubes; $\beta$-sheet.

\section{ВУГЛЕЦЕВІ НАНОТРУБКИ ПЕРЕШКОДЖАЮТЬ ЧИ СПРИЯЮТЬ ФОРМУВАННЮ АМІЛОЇДНИХ ФІБРИЛ? \\ М.В. Оленчук ${ }^{1}$, О.П. Гнатюк ${ }^{1}$, Г.І. Довбешко ${ }^{1}$, І.О. Польовий ${ }^{1}$, С.О. Карахім² \\ ${ }^{1}$ Інститут фізики НАН України, проспект Науки 46, Київ, 03028, Украӥна \\ ${ }^{2}$ Інститут біохімії ім. О.В. Палладіна, вул. Леонтовича, 9, Київ, 01601, Украӥна}

Актуальність. Вуглецеві нанотрубки, завдяки своїм унікальним фізичним властивостям, знайшли широке застосування в матеріалознавстві та електроніці, однак численні спроби створення систем доставки ліків чи комплексів терапевтичних препаратів 3 нанотрубками 3 метою покращення ефективності та специфічності їх дії не призвела до успіху. В першу чергу це пов'язано з високою цитотоксичністю нанотрубок для живих клітин та відсутністю механізмів їх біодеградації. 3

(C) Olenchuk M.V., Gnatyuk O.P., Dovbeshko G.I., Polovyi I.O., Karakhim S.O., 2019 
M.V. Olenchuk, O.P. Gnatyuk, G.I. Dovbeshko, I.O. Polovyi, S.O. Karakhim

іншого боку, вуглецеві нанотрубки можуть утворювати стійкі комплексами 3 такими біологічно важливими молекулами як ДНК, фосфоліпіди, білки. В даній роботі показана можливість формування амілоїдних фібрилярних структур в лізоцимі при взаємодії 3 вуглецевими нанотрубками. Отримані результати мають як фундаментальне, так і прикладне значення, оскільки це може бути методом отримання модельних амілоїдних фібрил для подальшого вивчення.

Мета роботи. Метою роботи було дослідити вплив вуглецевих нанотрубок на процес утворення фібрилярних структур в лізоцимі при кімнатній температурі при різних значеннях $\mathrm{pH}$.

Матеріали і методи. Для приготування експериментальних зразків був використаний лізоцим, виділений з білка курячих яєць (HEWL - Hen Egg-White Lysozyme, Fluka), а також одностінні (SWCNT, Sigma-Aldrich) та багатостінні (MWCNT, OOO TM «Спецмаш», Київ, Україна) вуглецеві нанотрубки. Використані методики: ІЧ-Фур'є-спектроскопія поглинання; конфокальна мікроскопія.

Результати. В даній роботі проведено дослідження молекулярних механізмів взаємодії лізоциму 3 вуглецевими нанотрубками методом коливальної спектроскопії та проведено конформаційний аналіз утворених комплексів. Показано, що вуглецеві нанотрубки можуть впливати на просторову структуру лізоциму навіть при кімнатній температурі та нормальних значеннях рН, про що свідчать конформаційні зміни в лізоцимі внаслідок взаємодії з вуглецевими нанотрубками. Комплекси, утворені внаслідок такої взаємодії, мають характерні риси амілоїдних фібрилярних структур, що розкриває один з механізмів цитотоксичності вуглецевих нанотрубок. 3 іншого боку, така методика може бути впроваджена для отримання модельних амілоїдних фібрил з метою їх подальшого вивчення.

Висновки. Методом коливальної спектроскопії показано, що вуглецеві нанотрубки можуть впливати на просторову структуру лізоциму, про що свідчить конформаційний аналіз смуги поглинання Амід I. Після взаємодії лізоциму 3 ВНТ, відбувається збільшення вкладу антипаралельної $\beta$-конформації в структурі лізоциму, та зменшення вкладу $\alpha$-спіральної конформації, що $\epsilon$ характерними рисами при формуванні фібрилярних структур. Показана можливість утворення амілоїдних фібрилярних структур без застосування високих температур при різних значеннях $\mathrm{pH}$ при взаємодії лізоциму 3 вуглецевими нанотрубками, що може мати прикладне застосування в якості методу отримання модельних амілоїдних фібрил.

КЛЮЧОВІ СЛОВА: амілоїдні фібрили; лізоцим; вуглецеві нанотрубки; $\beta$-шари.

\section{УГЛЕРОДНЫЕ НАНОТРУБКИ ПРЕПЯТСТВУЮТ ИЛИ ВЫЗЫВАЮТ ФОРМИРОВАНИЕ АМИЛОИДНЫХ ФИБРИЛЛ? \\ М.В. Оленчук ${ }^{1}$, Е.П. Гнатюк ${ }^{1}$, Г.И. Довбешко ${ }^{1}$, И.А. Полевой ${ }^{1}$, С.А. Карахим² \\ ${ }^{1}$ Институт физики НАН Украины, проспект Науки 46, Киев, 03028, Украина \\ ${ }^{2}$ Институт биохимии им. О.В. Палладина, ул. Леонтовича, 9, Киев, 01601, Украина}

Актуальность. Углеродные нанотрубки, благодаря своим уникальным физическим свойствам, нашли широкое применение в материаловедении и электронике, однако многочисленные попытки создания систем доставки лекарств или комплексов терапевтических препаратов с нанотрубками с целью повышения эффективности и специфичности их действия не привела к успеху. В первую очередь это связано с высокой цитотоксичностью нанотрубок для живых клеток и отсутствием механизмов их биодеградации. С другой стороны, углеродные нанотрубки могут образовывать устойчивые комплексы с такими биологически важными молекулами как ДНК, фосфолипиды, белки. В данной работе показана возможность формирования амилоидных фибриллярных структур из лизоцима при взаимодействии с углеродными нанотрубками. Полученные результаты имеют как фундаментальное, так и прикладное значение, поскольку это может быть способом получения модельных амилоидных фибрилл для дальнейшего изучения.

Цель работы. Целью работы было исследовать влияние углеродных нанотрубок на процесс образования фибриллярных структур в лизоциме при комнатной температуре при различных значениях $\mathrm{pH}$.

Материалы и методы. Для приготовления экспериментальных образцов был использован лизоцим, выделенный из белка куриных яиц (HEWL - Hen Egg-White Lysozyme, Fluka), а также одностенные (SWCNT, Sigma-Aldrich) и многостенные (MWCNT, OOO TM «Спецмаш», Киев, Украина) углеродные нанотрубки. Использованы методики: ИК-Фурье-спектроскопия поглощения; конфокальная микроскопия.

Результаты. В данной работе проведено исследование молекулярных механизмов взаимодействия лизоцима с углеродными нанотрубками методом колебательной спектроскопии и проведен конформационный анализ образованных комплексов. Показано, что углеродные нанотрубки могут 
влиять на пространственную структуру лизоцима даже в условиях комнатной температуры и нормальных значений $\mathrm{pH}$, о чем свидетельствуют конформационные изменения в лизоциме в результате взаимодействия с углеродными нанотрубками. Комплексы, образованные в результате такого взаимодействия, имеют характерные черты амилоидных фибриллярных структур, раскрывают один из механизмов цитотоксичности углеродных нанотрубок. С другой стороны, такая методика может быть введена для получения модельных амилоидных фибрилл с целью их дальнейшего изучения.

Выводы. Методом колебательной спектроскопии показано, что углеродные нанотрубки могут влиять на пространственную структуру лизоцима, о чем свидетельствует конформационный анализ полосы поглощения Амид I. После взаимодействия лизоцима с УНТ, происходит увеличение вклада антипараллельной $\beta$-конформации в структуре лизоцима, и уменьшение вклада

$\alpha$-спиральной конформации, которые являются характерными чертами при формировании фибриллярных структур. Показана возможность образования амилоидных фибриллярных структур без применения высоких температур при различных значениях рН при взаимодействии лизоцима с углеродными нанотрубками, что может иметь прикладное применение в качестве метода получения модельных амилоидных фибрилл.

КЛЮЧЕВЫЕ СЛОВА: амилоидные фибриллы; лизоцим; углеродные нанотрубки; $\beta$-слои.

A key issue in the amyloid science is to understand a mechanism of the amyloid fibril formation and its connection with pathological state of a living body [1] It is known that amyloid fibril arising is correlate with a number of diseases such as Alzheimer and Parkinson diseases, prion propagation, cancer geneses and metastases progress etc [2]; moreover, amyloid fibrils can appear in a variety of different morphological shapes [3-5].

Lysozyme (Lys), a small protein with four disulfide bonds, stems a property of bactericidal enzyme. It was found in a salivary fluid, in human tears, in the protein of hen egg. It is able to destroy the cell wall of gram-negative bacteria and some types of fungi. It contains 129 amino acid residues. Lysozyme is one of the most intensively studied proteins, especially, it is often used as a model system for amyloid fibril formation study [6, 7]. The amyloid fibril is a type of insoluble protein that aggregate with a specific secondary structure. [3-5, 8-10]. Lysozyme is not associated with any known amyloid diseases; however, it shares similar morphological features with amyloids from disease associated proteins. Study of mechanism of amyloid formation extends our knowledge about fibril formation and assists to clear up a possible disadvantage of interaction between nanoparticles and amyloids.

Carbon nanotubes (CNTs) are the most investigated carbon nanomaterials due to their unique physical and chemical characteristics, cheap and easy production, stability and indispensability for improving of electrical and mechanical properties of materials. Last years the carbon nanotubes are used as supporting matrix for protein adsorption and isolation [11]. Thus, Yuan et al. used Multiwalled carbon nanotubes (MWCNT) as a carrier to prepare lysozyme imprinted polymers or even separation of lysozyme from egg white. However, the question arises: how do CNTs influence the amyloid fibrils formation. A fact about solubility of carbon nanotubes in the presence of fibril-forming protein lysozyme is an additional argument indicating easy possibility for fibril appearing [12-14]. However, a computer simulation of a CNT interaction with lysozyme done in [2] showed another possibility, namely, breaking of fibrils in the presence of CNT. So, the question about the CNT role in the fibrils breaking and formation is important. That is why the subject of our research was to study an influence of carbon nanotubes on fibril formation in vitro model experiment.

\section{MATERIALS AND METHODS}

Hen egg white lysozyme (HEWL) was purchased from Fluka and used without further purification. MWCNT were provided by OOO TM "Spetsmash", Kiev, Ukraine. They were obtained by catalytic pyrolysis of acetylene with the outer diameter 2-40 nm, the number of walls from 2 to 15 and the length up to $50 \mu \mathrm{m}$, and treated from catalyst residues by 
hydrofluoric acid. Single walled carbon nanotubes (SWCNT) were bought from SigmaAldrich, with the diameter of 1.4-1.5 nm and the length about 1-2 $\mu \mathrm{m}$.

The process of preparation of amyloid fibrils included ultrasonic treatment of aqueous solution of nanotubes (three times), followed by the selection of the central transparent part of the solution. Thereafter, an aqueous suspension of nanotubes was added to the aqueous solution of lysozyme (concentration $1 \mathrm{mg} / \mathrm{ml}$ ).

In this study we did not use surface-active substances intentionally because they could affect the formation of amyloid fibrils and could also provide additional absorption bands in vibrational spectra, which significantly distort the analysis of results.

An aqueous suspension of SWCNT was prepared by ultrasonification at $60 \mathrm{~W}$ and $22 \mathrm{kHz}$ for 3 hours. $1 \mathrm{mg}$ of HEWL was dissolved in $1 \mathrm{ml}$ of distilled water $(\mathrm{pH}=5.5)$. This solution was acidified to $\mathrm{pH}=2.5$ with $\mathrm{HCl}$ addition or alkalified to $\mathrm{pH}=11.5$ with $\mathrm{KOH}$. An aqueous suspension of MWCNT was added to the prepared lysozyme solution and incubated for 14 days at room temperature. An aqueous suspension of SWCNT was added to the prepared lysozyme solutions and incubated for 2 days at $50^{\circ} \mathrm{C}$. For the IR absorption spectra registration and confocal imaging, the samples were dropped onto a rough gold surface and dried.

The IR spectra were collected in the $400-7000 \mathrm{~cm}^{-1}$ region with an IFS-66 Bruker instrument with resolution of $0.5 \mathrm{~cm}^{-1}$ and wavenumber definition accuracy of not less than $0.01 \mathrm{~cm}^{-1}$. Repeatability of frequency in our IR spectra measurements was $0.5 \mathrm{~cm}^{-1}$ and that of absorbance - about 0.0005 . The IR spectra of proteins were measured in the external reflection configuration at the light incidence angle $16.5^{\circ}$, as described in [15.16]. Deconvolution and decomposition of the spectral bands were performed with Opus-5.5 software program. The peak positions of the absorption bands were estimated by using the second derivative method and/or the standard Opus-5.5 peak finding method. All spectra were baseline-corrected and normalized by the peak intensity of $\mathrm{O}-\mathrm{H}$ stretching vibrations band centered near $3300 \mathrm{~cm}^{-1}[16,17]$.

Confocal imaging was carried out with a Carl Zeiss LSM-510 META confocal laser scanning microscope withthe 4D Plan-Neofluar 40x/0.6 Korr oil immersion objective in Multi Track mode. For observing objects in a transmittance mode in visible light a halogen incandescent lamp was used. A fluorescence images of the objects were obtained by excitation with ultraviolet mercury lamp HBO-100 or with diode laser $(\lambda=405 \mathrm{~nm}, 25 \mathrm{~mW})$, Ar orArKr laser $(\lambda=488 \mathrm{~nm}, 30 \mathrm{~mW})$ and HeNe laser $(\lambda=633 \mathrm{~nm}, 5 \mathrm{~mW})$ in backscattering geometry. Magnification in the experiments was $\mathrm{x} 40$ and $\mathrm{x} 10$. The most important optical advantage of confocal microscopy is that the radiated photons are focused by the objective lens on a small $(\sim 50 \mu \mathrm{m})$ detector pinhole which limits a depth of focus and cut other photons by pinhole causing better contrast in comparison with other types of optical microscopes.

\section{RESULTS AND DISCUTION}

To analyze the contribution of antiparallel $\beta$-layers in the spatial structure of HEWL, conformational analysis of the IR absorption bands of the lysozyme Amide I $\left(1700-1600 \mathrm{~cm}^{-1}\right.$ ) was done (Fig. 1).

This part of the IR absorption spectrum gives a lot of information about the protein secondary structure and conformational changes. The Amide I band is mainly due to $\mathrm{C}=\mathrm{O}$ stretching vibration (approximately $80 \%$ ) of the amide groups coupled with in-plane $\mathrm{NH}$ bending $(<20 \%)$.

The set and position of the bands for a fitting were selected according to the literature data [18-20] of conformational states of lysozyme to certain positions of the bands of Amid I. The conformational state of the protein in amyloid fibrils differs from that in initial protein 
and results in the appearance of the new conformation, namely, antiparallel $\beta$-layers, which were not found in reference sample.

In order to mark the antiparallel $\beta$-sheet, we performed a model experiment for the amyloid fibril formation under standard conditions $\left(2\right.$ days at $\left.50^{\circ} \mathrm{C}\right)$ and at different $\mathrm{pH}$.

With the vibrational spectra analysis we found that markers of antiparallel $\beta$-layers conformation are in the region of $1687-1695 \mathrm{~cm}^{-1}$ and $1615-1625 \mathrm{~cm}^{-1}$. Thus, in the fitting processes we must consider the appearance of this new conformation, so the number of components in the reference sample and in the amyloid will be different. In the case of incubation with MWCNT, the total contribution of $\beta$-sheet increases by about $10 \%$ compared to that for SWCNT.

Quantitative analysis of the protein secondary structure is based on the assumption that secondary structure can be presented as a contributions of all conformations. The components of the Amide I band can be determined by considering their frequency and intensity behavior.

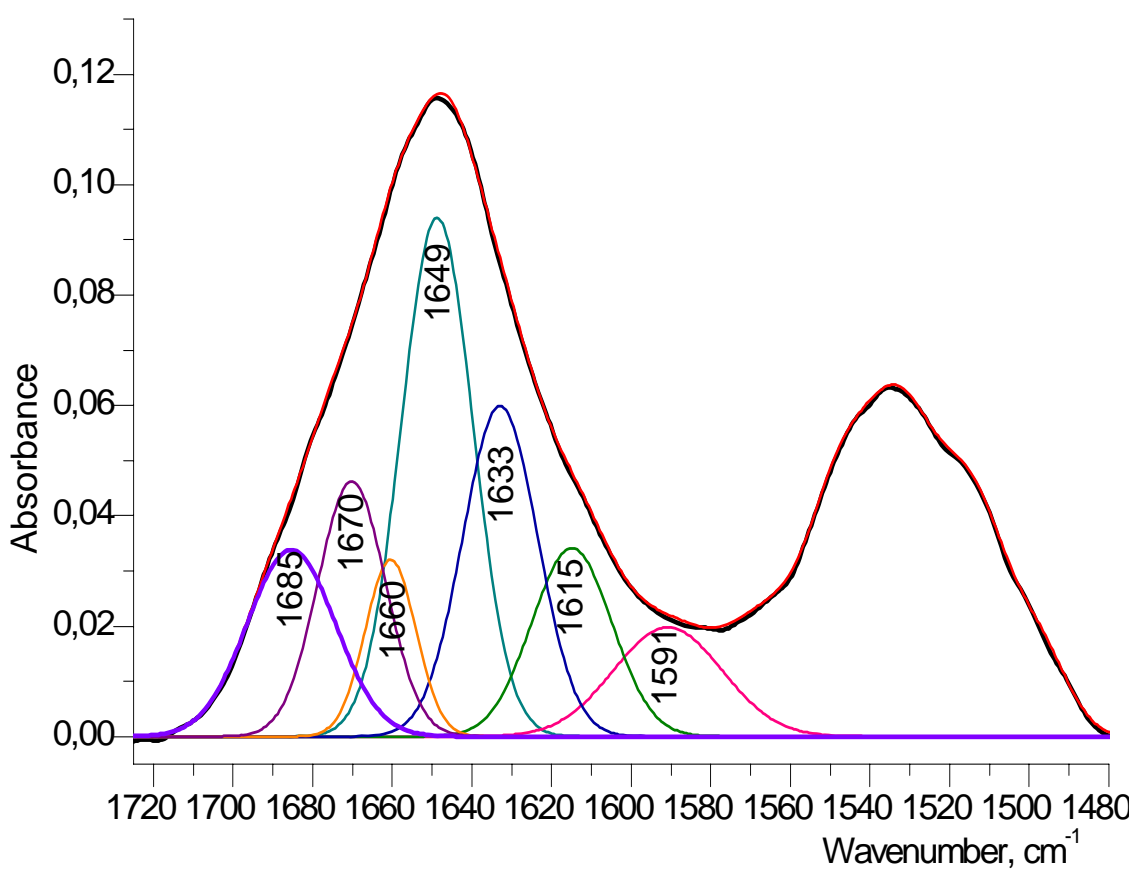

Fig. 1. Component analysis of Amid I IR absorption bands of HEWL, pH 5.3.

The biological activity of CNTs relative to proteins was checked with FTIR spectroscopy. It was shown that after the interaction of the proteins with MWCNT, the relative percentage content of $\beta$-conformation in the structure of the proteins increases, and an unordered state of the protein decreases. Thus, our experimental studies confirm the possibility of forming the structures harmful to human body upon interaction of HEWL with CNTs.

Our results show that the protein structural composition is the following: $\alpha$-helix $28.17 \%$, $\beta$-turn $-13.07 \%, \beta$-sheet $-31.38 \%$, disordered structure $-27.38 \%$. The similar secondary structure of lysozyme dissolved in water was determined from the far-UV CD spectra [6]. We suppose that peaks at $1615 \mathrm{~cm}^{-1}$ and $1685 \mathrm{~cm}^{-1}$ are formed by the contribution of $\beta$-sheet and side groups in the reference [21]. After interaction with SWCNT structural composition is similar to reference HELW, but we see a small part antiparallel form $(6.59 \%)$ in the $\beta$-sheet (Fig. 2 b). After interaction with MWCNT, the protein undergoes structural changes (Fig. 2 a): the contribution from $\beta$-sheet, namely, antiparallel conformation increases $(16.24 \%)$ along with a decrease in the contribution from the disordered structure 
$(15.35 \%)$. Similar strong changes in the protein conformation indicate the formation of the amyloid fibril structures [18-20].

A new absorption peak at $1620 \mathrm{~cm}^{-1}$ (Fig. 2 a) and $1616 \mathrm{~cm}^{-1}$ (Fig. 2 b) corresponds to the appearance of a new conformation, likely HEWL amyloid fibril [6]. Peaks at $\sim 1635 \mathrm{~cm}^{-1}$ and at $\sim 1685 \mathrm{~cm}^{-1}$ are characteristic of $\beta$-sheet structure [21]. A peak about $1694 \mathrm{~cm}^{-1}$ is characteristics of antiparallel form in the $\beta$-sheet (Fig. 2 b) [16]. In the case of MWCNT, the fitting of the system gives $1699 \mathrm{~cm}^{-1}$ peak. The shift of the peak in high frequency region could be explained by additional interaction in the system MWCNT-protein. The results of spectra fitting show an interaction of MWCNT and SWCNT with lysozyme for both cases (Fig. 2). Thus, in the Fig. 2, we see a larger (about 10\%) contribution of antiparallel $\beta$-sheet conformation in the case of HEWL+MWCNT in comparison with the same for HEWL+SWCNT. This conclusion is in accordance with the data from [13] wherelysozyme has stronger interaction with larger diameter of nanotubes that could assist better fibril formation.

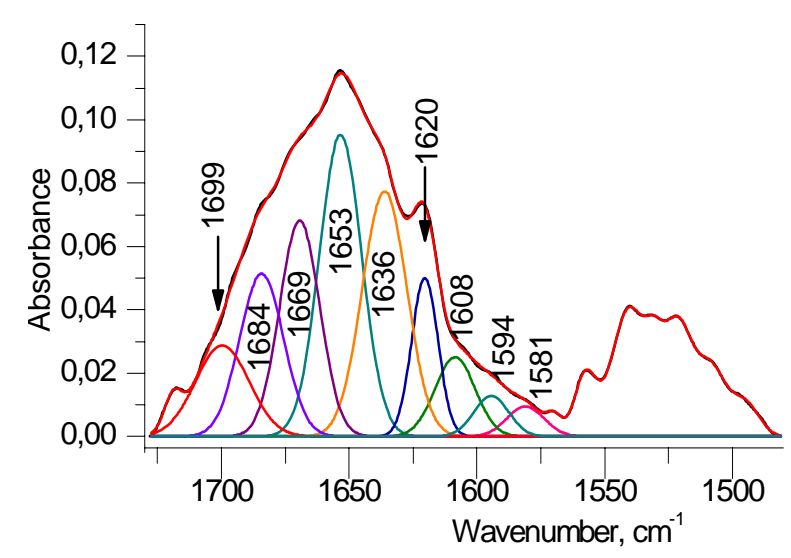

a

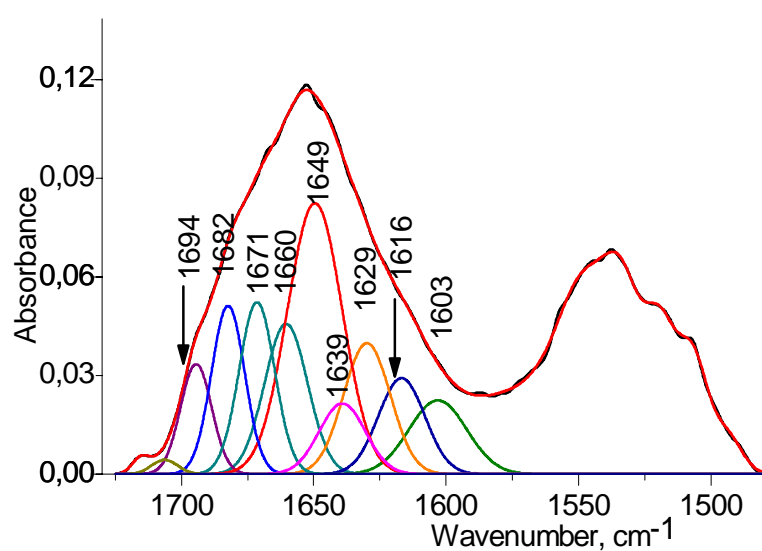

$\mathrm{b}$

Fig. 2. Component analysis of Amid I and Amid II IR bands of HEWL+MWCNT at pH 5.5 (a) and 1580 HEWL+SWCNT at pH 6.0 (b).

For comparison we added also all spectra for all the samples under neutral $\mathrm{pH}$ (5.5-6) on one figure, from which we can clearly see appearance of the antiparallel beta-sheet conformation $\left(1621 \mathrm{~cm}^{-1}\right.$ and $1696 \mathrm{~cm}^{-1}$ in Lys+MWCNT and $1614 \mathrm{~cm}^{-1}$ in Lys+SWCNT) (Fig. 3). These peaks are clearly distinguished on the shoulders of wider Amid I bands of the sample with carbon nanotubes in comparison to reference sample.

In confocal microscopy image at $\mathrm{pH}=5.5$ (Fig. 4 a) the lysozyme does not show fibril structure; similarly, we have not observed the formation of fibrils for lysozyme+SWCNT complex (Fig. 4 b, c), too. At normal pH for SWCNT and MWCNT, we observed the formation of a continuous thin film of protein, a thickness of about 0.5 microns, in which we do not observe fibrillar structures. We see aggregation of CNTs presented by black points inside of the film of lysozyme (Fig. 4).

The colorful bands we see in the images are of an interference nature and indicate that the film is heterogeneous and has a different thickness. Black strips are cracks of the crystal film of lysozyme. Multiple black dots in Fig. $4 \mathrm{~b}$ and c we assign to carbon nanotubes.

Inthecase of lysozyme+SWCNT complex dense nuclei from lysozyme are formed (Fig. 4 b and Fig. 5 b, respectively). We can suggest that this is a state of the fibril film formation with participation of SWCNT and/or MWCNT, supported by FTIR spectroscopy. 


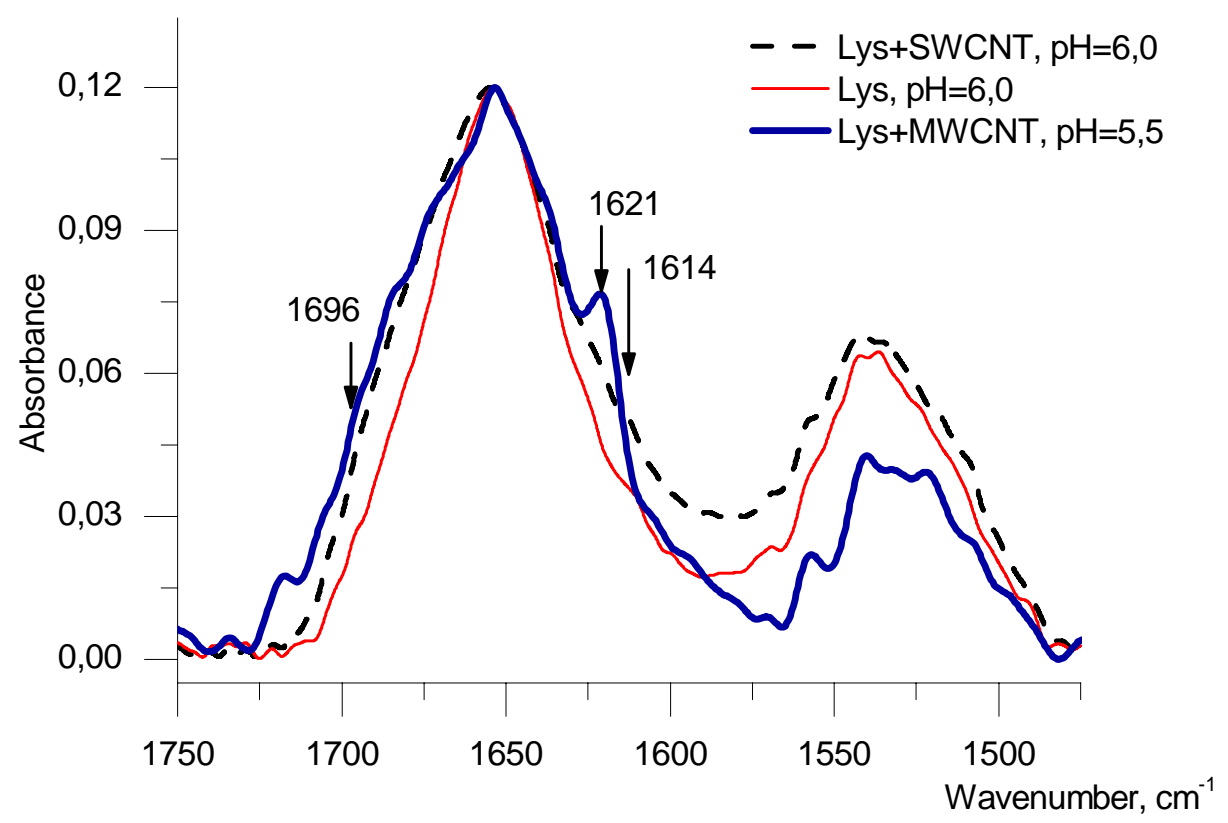

Fig. 3. IR spectra of lysozyme Amid I and Amid II regions: HEWL+SWCNT (dot line), HEWL (thin line), HEWL+MWCNT (thick line).
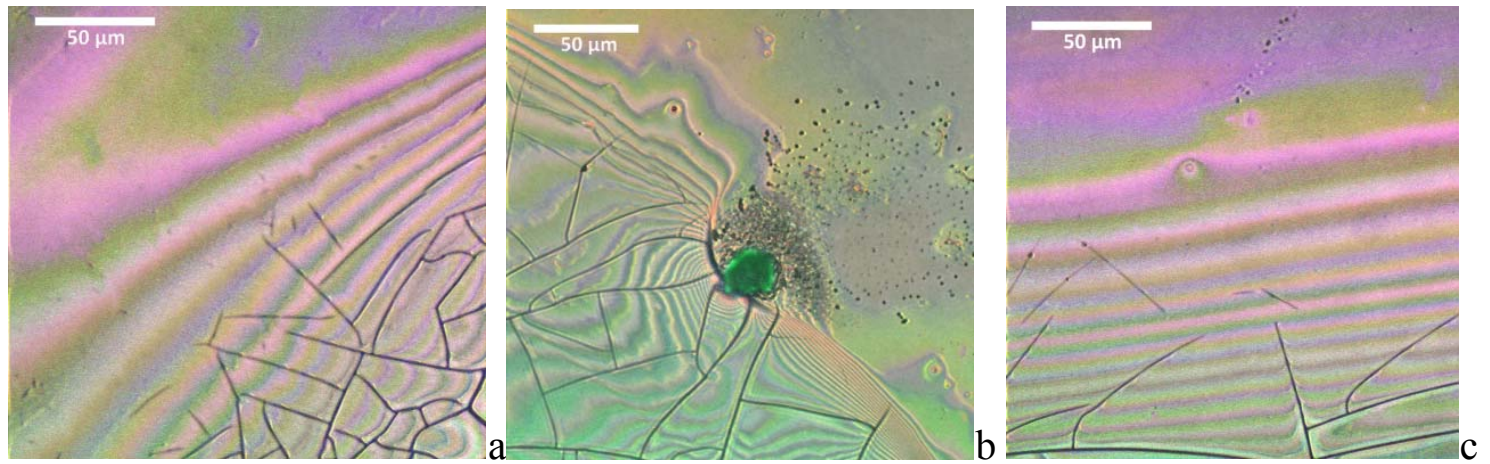

Fig. 4. Confocal images of pure HEWL (a), HEWL+SWCNT (b), HEWL+MWCNT (c) under pH=5.5.

We suppose that the fibrils come close one to another and form solid-like film [22] as in the case of the local larger protein concentration being a result of film thickness variation. The confocal microscopy data are not in accordance with FTIR fitting data and the conclusion about fibril features appearance in the Amid I spectral region.

IR spectra in the region of Amid I for all the samples of Lys obtained under 11.7 are similar. (Fig. 5) In the case of alkaline $\mathrm{pH}$, the shape of Amid I band is mostly determined by $\mathrm{pH}$ of the sample, and the spectra have negligible differences. Due to the dominant contribution of beta conformation in protein structure, which has maximum at $1628 \mathrm{~cm}^{-1}$, we could not registered low frequency shoulder located near $1614 \mathrm{~cm}^{-1}$ assigned to antiparallel beta conformation. Meanwhile high frequency of antiparallel beta conformation near $1693 \mathrm{~cm}^{-1}$ we can find at $1693 \mathrm{~cm}^{-1}$ for both samples (Fig. 5).

For a sample of lysozyme without nanotubes at an alkaline value of the $\mathrm{pH}$ (Fig. $6 \mathrm{a}, \mathrm{pH}$ 11.5), the size of the observed fibrillar aggregates is smaller than with the nanotubes (Fig. 6 b, $\mathrm{c}, \mathrm{pH}$ 11.5). Here we registered clear, elongated structures with a diameter up to several microns and a length of tens of microns or more. 


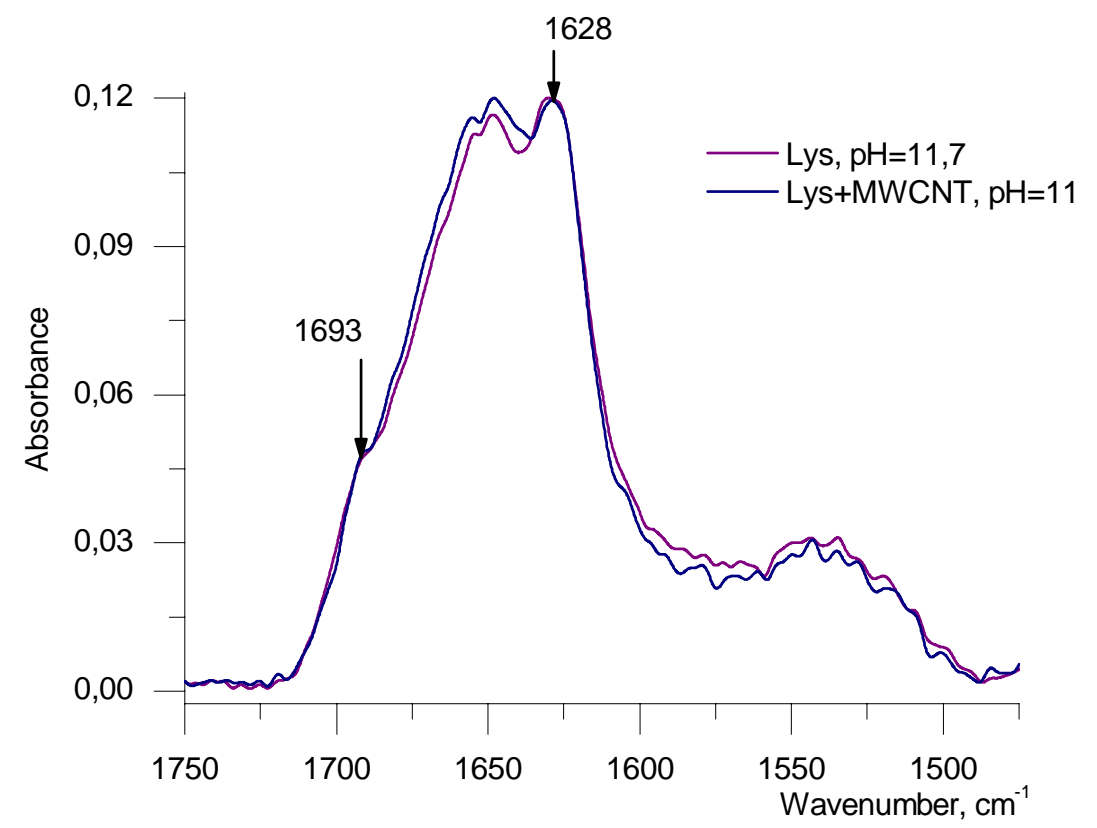

Fig. 5. IR spectra of lysozyme Amid I and Amid II regions: HEWL (thin line), HEWL+MWCNT (thick line).

Confocal microscopy cannot record structures with thin diameter (from units totens of nanometer), which is characteristic for fibril at initial stage of its formation. However, earlier [23-27] it was shown that the centroid of an image of the spot can be used to locate the object far beyond the resolution limit, despite the fact that the actual object size in the image can significantly differ from microscopy data.

We suggested that the size of actual fibrillar aggregates varies up to the size of a pixel. According to Nyquist criteria for digital resolution, the smallest resolved objects should have $\sim 2.3$ pixels [23].

According to the confocal microscopy resolution, for wavelength of $405 \mathrm{~nm}$, optical resolution of obtained images is

$$
d=0.4 \frac{\lambda}{N A}=216 \mathrm{~nm},
$$

where NA is numerical aperture of the objective, $\lambda$ is wavelength. Next, the size of a pixel is calculated being equal $94 \mathrm{~nm}$ in our case. However, the location of the luminescent object can be estimated with nanometer precision for the images with a high signal-noise ratio. [24-27]

In case of SWCNT, we observed ramified net of fibrillar aggregates (Fig. 6 b, pH 11.5,). In case of MWCNT on the background of small size structures (micron and less) we observed distinct elongated structures of $50 \mu \mathrm{m}$, which are corresponding to the size of carbon nanotubes used in our experiment. (Fig. $6 \mathrm{c}, \mathrm{pH} 11.5$ )

In contrast to high $\mathrm{pH}=11.7$ (Fig. 5) in the case of low $\mathrm{pH}=2.5$ (Fig. 7) fibrils seems to form more easily. Thus, in the sample of Lys+MWCNT at $\mathrm{pH} 2.5$ we registered beta conformation at $1626 \mathrm{~cm}^{-1}$, but in this sample (Lys+MWCNT) we could not distinguish low frequency shoulder at $1615 \mathrm{~cm}^{-1}$, at the same time high frequency shoulder at $1962 \mathrm{~cm}^{-1}$ appears. However, for the samples Lys and Lys+SWCNT we registered low frequency shoulder at $1613 \mathrm{~cm}^{-1}$ assign to beta conformation.

Therefore, MWCNT possesses more significant effect than SWCNT. We suppose that influence form both $\mathrm{pH}$ and MWCNT are being added. (Fig. 7) 

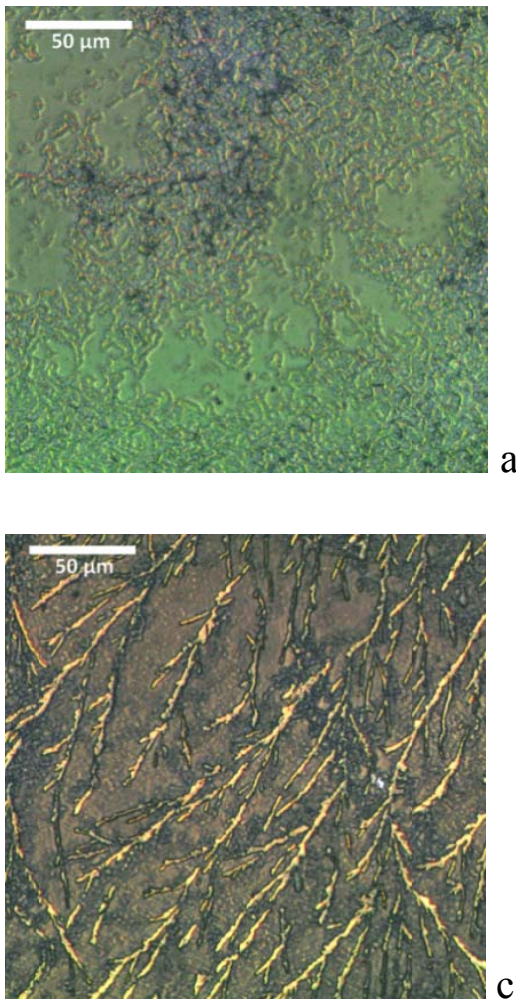

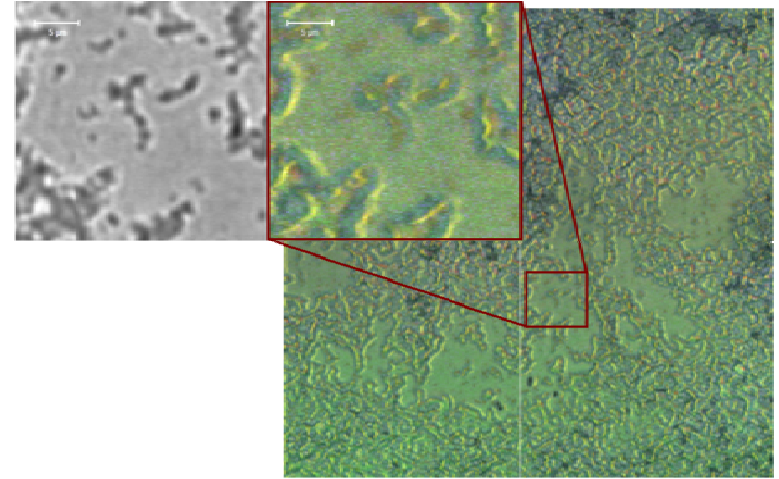

b

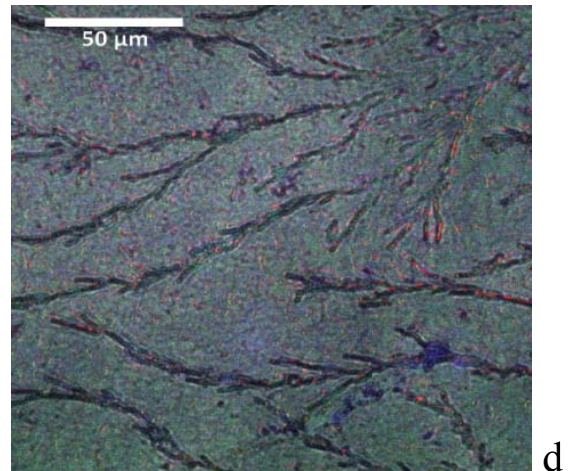

Fig. 6. Confocal images of pure HEWL (a,b), HEWL+SWCNT (c), HEWL+MWCNT (d) under pH=11.5.

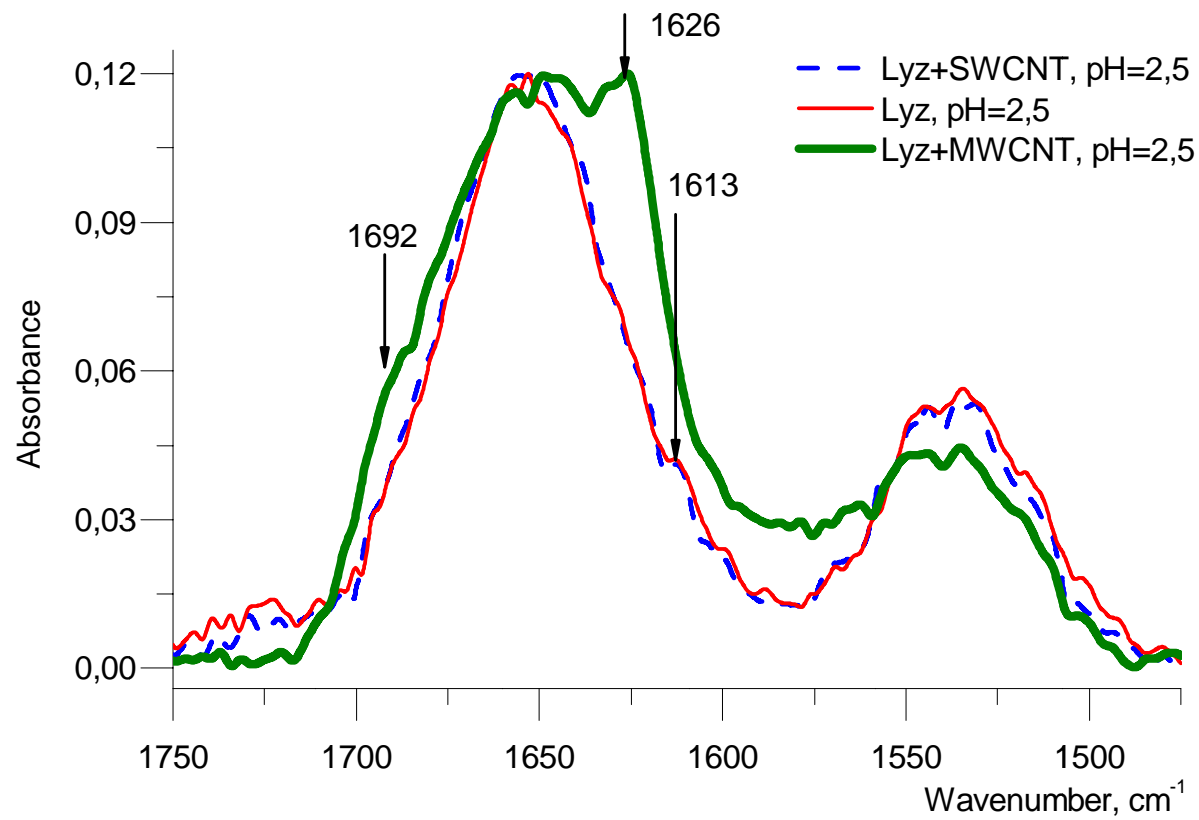

Fig. 7. IR spectra of lysozyme Amid I and Amid II regions: HEWL+SWCNT (dot line), HEWL (thin line), HEWL+MWCNT (thick line).

In case of acidic $\mathrm{pH}$ of the sample, we observe separated, seldom located fibrillar aggregates in confocal images. These aggregates were located more tightly in case of MWCNT (Fig. 8, c, pH 2.5), in comparison to those with SWCNT (Fig. 8, b, pH 2.5), and the sample without nanotubes (Fig. 8, a, $\mathrm{pH} 2.5$ ). 
Nanotubes serve as a surface, on which the formation of amyloid fibrils occurs more effectively. Surface of SWCNT and MWCNT have similar properties. Therefore, SWCNT and MWCNT influence the amyloid fibril formation similarly.
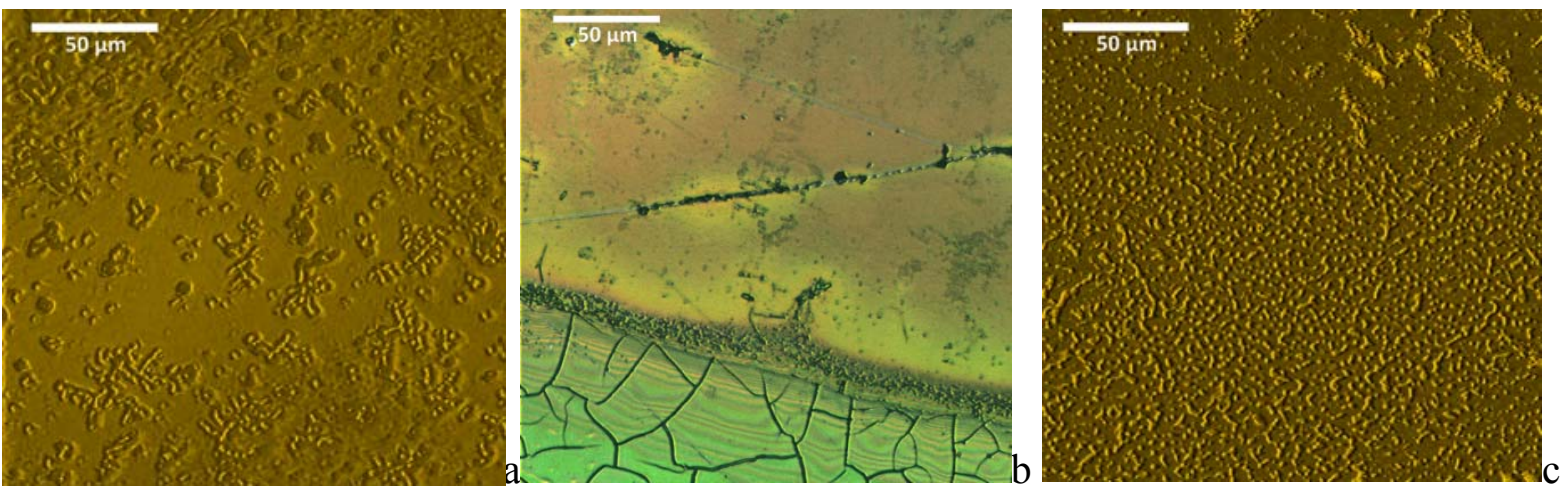

Fig. 8. Confocal images of pure HEWL (a), HEWL+SWCNT (b), HEWL+MWCNT (c) under pH=2.5.

Since the concentration of nanotubes was significantly (several orders of magnitude) lower than the concentration of lysozyme, the size of amyloid aggregates ranged up to several microns in diameter and $10 \mu \mathrm{m}$ in length, which agrees with [23].

\section{CONCLUSION}

Summarizing, using FTIR spectroscopy and confocal microscopy, we have found out that CNTs could be a good promoter to initiate the process of fibril formation even under the room temperature and $\mathrm{pH}$ range of 5.5-6. The effect of amyloid fibril formation under different physiological conditions could be modeled by presence of CNT in lysozyme solution. The mechanism of this effect seems to be connected with good absorbance of lysozyme on the CNT and matches their surfaces. The relationship of the revealed effect with the diseases should be studied in vivo.

\section{ACKNOWLEDGMENT}

This work has been supported by the HORIZON 2020 project "Asymmetry of biological membrane: theoretical, experimental and applied aspects" (690853-assymcurv-H2020-MSCARISE-2015/ H2020-MSCA-RISE-2015), NATO 98 5291, STCU 6175, "Development of 2D materials and "smart" sensors for medical and biological purposes" 11/12018.

This paper is dedicated by the authors to the memory of a prominent Ukrainian physicist and biophysicist Professor Blagoi Yuri Pavlovych. We are grateful to Yuri Pavlovych for the sharing of invaluable scientific experience in the field of interaction between DNA and other biological molecules with metal ions, mutual creative work. The authors of the paper thank to all the co-authors of the cited papers for their cooperation.

\section{CONFLICT OF INTEREST}

The authors report that there is no conflict of interest.

\section{Authors' ORCID ID}

M.V. Olenchuk (i)https://orcid.org/0000-0002-3710-6349

G.I. Dovbeshko 1 https://orcid.org/0000-0002-7701-0106

O.P. Gnatyuk (Dhttps://orcid.org/0000-0003-4406-5503

I.O. Polovyi iD https://orcid.org/0000-0003-0149-7314

S.O. Karakhim (iD https://orcid.org/0000-0002-8389-0584 


\section{REFERENCES}

1. Annamalai, K., Gührs, K.-H., Koehler, R., Schmidt, M., Michel, H., Loos, C., Fändrich, M. (2016). Polymorphism of Amyloid Fibrils In Vivo. AngewandteChemie International Edition, 55(15), 4822-4825.

2. Li, H., Luo, Y., Derreumaux, P., \& Wei, G. (2011). Carbon Nanotube Inhibits the Formation of $\beta$-Sheet-Rich Oligomers of the Alzheimer's Amyloid-ß(16-22) Peptide. Biophysical Journal, 101(9), 2267-2276. https://doi.org/10.1016/j.bpj.2011.09.046

3. Close, W., Neumann, M., Schmidt, A., Hora, M., Annamalai, K., Schmidt, M., ...Fändrich, M. (2018). Physical basis of amyloid fibril polymorphism. Nature Communications, 9(1). https://doi.org/10.1038/s41467018-03164-5

4. Schmidt, A., Annamalai, K., Schmidt, M., Grigorieff, N., \&Fändrich, M. (2016). Cryo-EM reveals the steric zipper structure of a light chain-derived amyloid fibril. Proceedings of the National Academy of Sciences, 113(22), 6200-6205. https://doi.org/10.1073/pnas.1522282113

5. Liberta, F., Loerch, S., Rennegarbe, M., Schierhorn, A., Westermark, P., Westermark, G. T., ...Schmidt, M. (2018). Cryo-EM structure of an amyloid fibril from systemic amyloidosis. Cold Spring Harbor Laboratory. https://doi.org/10.1101/357129

6. Knubovets, T., Osterhout, J. J., Connolly, P. J., \&Klibanov, A. M. (1999). Structure, thermostability, and conformational flexibility of hen egg-white lysozyme dissolved in glycerol. Proceedings of the National Academy of Sciences, 96(4), 1262-1267. https://doi.org/10.1073/pnas.96.4.1262

7. Zou, Y., Hao, W., Li, H., Gao, Y., Sun, Y., \& Ma, G. (2014). New Insight into Amyloid Fibril Formation of Hen Egg White Lysozyme Using a Two-Step Temperature-Dependent FTIR Approach. The Journal of Physical Chemistry B, 118(33), 9834-9843. https://doi.org/10.1021/jp504201k

8. Riek, R., \& Eisenberg, D. S. (2016). The activities of amyloids from a structural perspective. Nature, 539(7628), 227-235. https://doi.org/10.1038/nature20416

9. Sipe, J. D., Benson, M. D., Buxbaum, J. N., Ikeda, S., Merlini, G., Saraiva, M. J. M., \&Westermark, P. (2016). Amyloid fibril proteins and amyloidosis: chemical identification and clinical classification International Society of Amyloidosis 2016 Nomenclature Guidelines. Amyloid, 23(4), $209-213$. https://doi.org/10.1080/13506129.2016.1257986

10. Annamalai, K., Liberta, F., Vielberg, M.-T., Close, W., Lilie, H., Gührs, K.-H., ...Fändrich, M. (2017). Common Fibril Structures Imply Systemically Conserved Protein Misfolding Pathways In Vivo. Angewandte Chemie International Edition, 56(26), 7510-7514. https://doi.org/10.1002/anie.201701761

11. Yuan, S., Deng, Q., Fang, G., Wu, J., Li, W., \& Wang, S. (2014). Protein imprinted ionic liquid polymer on the surface of multiwall carbon nanotubes with high binding capacity for lysozyme. Journal of Chromatography B, 960, 239-246. https://doi.org/10.1016/j.jchromb.2014.04.021

12. Gao, R., Zhang, L., Hao, Y., Cui, X., Liu, D., Zhang, M., \& Tang, Y. (2015). Novel polydopamine imprinting layers coated magnetic carbon nanotubes for specific separation of lysozyme from egg white. Talanta, 144, 1125-1132. https://doi.org/10.1016/j.talanta.2015.07.090

13. Horn, D. W., Tracy, K., Easley, C. J., \& Davis, V. A. (2012). Lysozyme Dispersed Single-Walled Carbon Nanotubes: Interaction and Activity. The Journal of Physical Chemistry C, 116(18), 10341-10348. https://doi.org/10.1021/jp300242a

14. Vaitheeswaran, S., \& Garcia, A. E. (2011). Protein stability at a carbon nanotube interface. The Journal of Chemical Physics, 134(12), 125101.https://doi.org/10.1063/1.3558776

15. Dovbeshko, G. I., Chegel, V. I., Gridina, N. Y., Repnytska, O. P., Shirshov, Y. M., Tryndiak, V. P., ... Solyanik, G. I. (2002). Surface enhanced IR absorption of nucleic acids from tumor cells: FTIR reflectance study. Biopolymers, 67(6), 470-486. https://doi.org/10.1002/bip.10165

16. Dovbeshko, G.I. (2009). Molecular mechanisms of interaction of biological molecules with nanostructures, ligands and low doses of ionizing and microwave irradiation. (Doctor of sciences dissertation, V.N. Karazin Kharkiv National University, Kharkiv). (in Ukrainian). Available from Vernadsky National Library of Ukraine (DS117134)

17. Dovbeshko, G.I., Chegel, V.I., Gridina, N.Ya.,Gnatyuk, O.P., Shirshov, Y.M., Tryndiak, V.P., and Todor, I.M. (2001). Surface enhanced infrared absorption of nucleic acids on gold substrate. Semiconductor Physics Quantum Electronics and Optoelectronics, 4(3), 202-206. https://doi.org/10.1117/12.429717

18. Dong A., Meyer J.D., Brown J.L., Manning M.C., Carpenter J. F. (2000) Comparative Fourier Transform Infrared and Circular Dichroism spectroscopic analysis of a1l-proteinase inhibitor and ovalbumin in aqueous solution. Arch. Biochem. Biophys. 383: 148-155. https://doi.org/10.1006/abbi.2000.2054

19. Goormaghtigh, E., Ruysschaert, J.-M., \&Raussens, V. (2006). Evaluation of the Information Content in Infrared Spectra for Protein Secondary Structure Determination. Biophysical Journal, 90(8), 2946-2957. https://doi.org/10.1529/biophysj.105.072017 
20. Pérez, C., \&Griebenow, K. (2000). Fourier-transform infrared spectroscopic investigation of the thermal denaturation of hen egg-white lysozyme dissolved in aqueous buffer and glycerol. Biotechnology Letters. 22(23), 1899-1905. https://doi.org/10.1023/a:1005645810247

21. Zandomeneghi, G., Krebs, M. R. H., McCammon, M. G., \&Fändrich, M. (2009). FTIR reveals structural differences between native $\beta$-sheet proteins and amyloid fibrils. Protein Science, 13(12), 3314-3321. https://doi.org/10.1110/ps.041024904

22. del Mercato, L. L., Pompa, P. P., Maruccio, G., Torre, A. D., Sabella, S., Tamburro, A. M., ...Rinaldi, R. (2007). Charge transport and intrinsic fluorescence in amyloid-like fibrils. Proceedings of the National Academy of Sciences, 104(46), 18019-18024. https://doi.org/10.1073/pnas.0702843104

23. Waters, J. C. (2009). Accuracy and precision in quantitative fluorescence microscopy. The Journal of Cell Biology, 185(7), 1135-1148. https://doi.org/10.1083/jcb.200903097

24. Churchman, L. S., Okten, Z., Rock, R. S., Dawson, J. F., \& Spudich, J. A. (2005). Single molecule highresolution colocalization of $\mathrm{Cy} 3$ and $\mathrm{Cy} 5$ attached to macromolecules measures intramolecular distances through time. Proceedings of the National Academy of Sciences, 102(5), 1419-1423. https://doi.org/10.1073/pnas.0409487102

25.Yildiz, A., \&Selvin, P. R. (2005). Fluorescence Imaging with One Nanometer Accuracy: Application to Molecular Motors. Accounts of Chemical Research, 38(7), 574-582. https://doi.org/10.1021/ar040136s

26. Huang, B., W. Wang, M. Bates, and X. Zhuang. (2008). Three-dimensional super-resolution imaging by stochastic optical reconstruction microscopy. Science, 319, 810-813.

27. Manley, S., Gillette, J. M., Patterson, G. H., Shroff, H., Hess, H. F., Betzig, E., \& Lippincott-Schwartz, J. (2008). High-density mapping of single-molecule trajectories with photoactivated localization microscopy. Nature Methods, 5(2), 155-157. https://doi.org/10.1038/nmeth.1176

28. Pawley J. B. (2006) Handbook of Biological Confocal Microscopy ( $3^{\mathrm{d}}$ ed.). Springer, New York: Science+Business Media, LLC.

29. Kovalska, V., Chernii, S., Cherepanov, V., Losytskyy, M., Chernii, V., Varzatskii, O., ...Yarmoluk, S. (2017). The impact of binding of macrocyclic metal complexes on amyloid fibrillization of insulin and lysozyme. Journal of Molecular Recognition, 30(8), e2622. https://doi.org/10.1002/jmr.2622 